\title{
Qohelet's concept of deity: A comparative-philosophical perspective
}

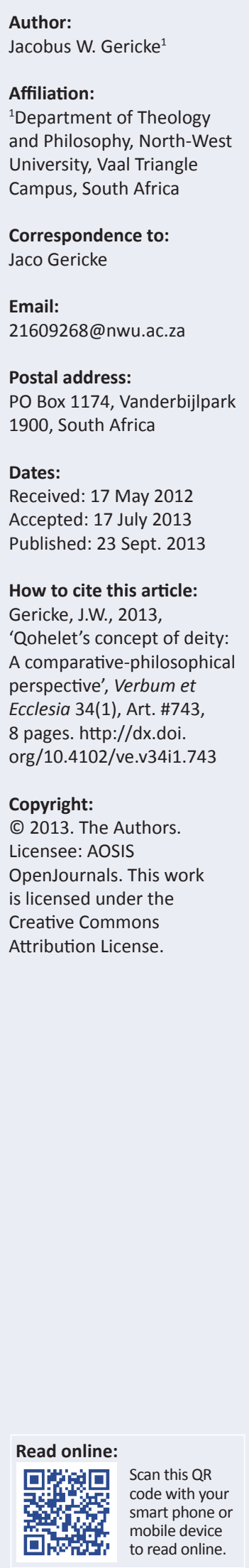

This article discusses the concept of deity in the book of Ecclesiastes (Qohelet) from the perspective of issues of interest in analytic philosophy of religion. Of concern are assumptions in the text about religion, the nature of religious language, religious epistemology, the concept of revelation, the attributes of the divine, the existence of God, the problem of evil, the relation between religion and morality and religious pluralism. A comparative philosophical clarification is offered with the aim of discerning similarities and differences between popular views in Christian philosophical theology and what, if anything, Qohelet took for granted on the same issues.

\section{Introduction}

The concept of deity is central to the interpretation of Ecclesiastes (henceforth Qohelet) (see Whybray 1998:239). Even so, the astute reader will note that there is little explicit theology in the book itself. Although the generic Hebrew term for the divine-elohim (with and without the definite article) - appears 40 times in the space of 12 chapters, the actual verses in which it occurs are generally unconnected and haphazardly related (Murphy 1992:17). Complicating the matter are contradictions in much of the book's statements on a variety of issues (see Loader 1979; Fox 1989). This means that stringing together references to the divine in the book does not constitute anything approximating a systematic theology of the book.

Perhaps for this reason, there do not seem to be many examples of in-depth research on the concept of deity in Qohelet. To be sure, commentators usually do have something to say about the ways in which the divine being is depicted in the text (see Armstrong 1983:16-25; Crenshaw 1984:73-74; Loader 1979:75, 129, passim; Longman 1998:35-36; Murphy 1987:253-260, 1991:30-33; Fox 1999:136-137; Seow 2000:91-116, 2001:237-249; Whybray 1998:239-265). However, very few studies have Qohelet's god as their primary and/or exclusive concern (see De Jong 1997:154167; Estes 1992; Hessler 1955:191-206; Limburg 2005; Lobdell 1981; Luder 1958:105-114; Michel 1975:87-100; Müler 1968:507-520).

To the relative lack of studies on Qohelet's notion of deity may be added an even more pervasive absence of attempts at a philosophical clarification of Qohelet's theology. General philosophical perspectives on aspects of Qohelet's thought do exist (see Anderson 1997; Aquino 1981; Braun 1973; Crenshaw 2009:41-62; Fox 1987:137-155; Lohfink 1990:20-25; O’Dowd 2007; Kreeft 1989). However, these discussions usually involve inquiries that do not focus philosophically and specifically on religious issues. Of interest have been the relations of Qohelet's wisdom to Greek (Hellenistic), Eastern or modern Western existentialist philosophies (see Palm 1885; Braun 1973; Murphy 1992:22-25; Crenshaw 2009:41-62; Eaton 1989; Fox 1989; Heard 1996:65-93).

Alternatively, Qohelet's ethics, epistemology and metaphysics (axiology in particular) are notable topics in philosophical commentary (Fox 1987:137-155; Lohfink 1990:20; Schellenberg 2002). Yet to this day, no attempt has been made to elucidate Qohelet's concept of deity from the perspective of issues of interest in analytic philosophy of religion (cf. Crenshaw 2009:41-62 [passim]).

Of course, Qohelet himself was no philosopher of religion in the modern sense of the discipline (see Long 2001:1). Yet in many Christian circles Qohelet's theology tends to be roped into the service of apologetic philosophy of religion. On the one hand some so-called 'conservative' perspectives distort the book's contents, insisting that Qohelet was actually trying to show the inevitability of nihilism in an atheist worldview (Bartholomew 1999:4-20; Caneday 1986:2156; Shank 1974:57-73; Zuck 1991:46-56). From a historical perspective this is a sincere albeit blatantly incorrect assessment of the author's intentions. Such a reading is usually motivated by the fundamentalist need to harmonise the book's unchristian theology with Church dogma and the desire to repress the reality of pluralism in Old Testament theologies. Qohelet was indeed a nihilist (see Gericke 2012:1-6) but was definitely not trying to show the futility of a life 
without God (contra Shank 1974:57-73; Caneday 1986:21-56; Zuck 1991:46-56; Bartholomew 1999:4-20). For Qohelet, nihilism is the truth in spite of a belief in the reality of the divine (see 1:12; 2:26; 3:11; 7:13-14; 8:16-17; 9:1-10; etc.; Gericke 2012:1-6).

On the other hand, many critical albeit pastoral interpreters try to show the contemporary relevance of Qohelet by hailing the author's heterodoxy and doubt as supposedly a corrective sort of anomaly within otherwise dogmatist Church theology (Brueggemann 1997:400; Davidson 1983:184). This too is a strategy of evasion because Qohelet's epistemological doubt, perhaps interesting to those who themselves struggle with faith, does not in turn make his theology commensurable with anything commentators still believe in today. Those who idealise or romanticise Qohelet's disillusionment as a type of the post-modern deconstruction of dogma conveniently confuse a kindred spirit with userfriendly theology. Qohelet's theology contains too much that just does not cater for the consumer culture of post-modern god-talk (see Sneed 2012; contra Murphy 1987:253-260; Brueggemann 1997:393-398). Nevertheless, the book contains more superstitious, conservative and uncritical notions than those hailing him as the patron saint of biblical radicalism will admit to (see Sneed 2012).

This article does not aim to show the relevance of Qohelet's theology for contemporary Jewish or Christian theology. I have no intention of constructing a normative philosophy of religion from its complex contents. Instead, the discussion focuses on something approximating a comparative philosophy of religion working in tandem with the history of religion in order to identify assumptions in the book's godtalk related to issues on the agenda in analytic philosophy of religion. Whilst the book of Qohelet was not composed with the intention of answering questions on these issues, it is perfectly appropriate to ask what (if anything) the text might have presupposed on related matters.

\section{Topoi in analytic philosophy of religion}

An attempt will be made to introduce Qohelet's assumptions regarding religion, the nature of religious language, religious epistemology, the concept of revelation, the attributes of deity, the existence of deity, the problem of evil, the relation between religion and morality and religious pluralism. These are some of the standard issues of interest in analytic philosophy of religion (see Harris 2002).

In offering this new perspective on Qohelet's theology, the article's arguments are limited by two unavoidable constraints. First of all, due to pluralism in the philosophy of religion, much of what is said here of necessity involves stereotyping and generalisation. Secondly, the spatial limitations involved in writing a journal article make it impractical to become involved in controversies surrounding the complex redaction history of the book. In discussing 'Qohelet's perspective' I am referring to the book as a whole, namely the incommensurable theologies put forward by all the book's personas (e.g. the fictional character of Solomon, Qohelet the sage, editorial expansions, the frame-narrator's evaluative point of view, etc.).

\section{The nature of religion in Qohelet}

The first locus of this type of course concerns the nature of religion, and problems with defining the concept (GriffithsDickson 2005:60-108). A variety of technically reductionist perspectives are available from anthropological, sociological, psychological, philosophical and theological definitions. Following Wittgenstein, however, many contemporary philosophers of religion prefer a 'family resemblance' approach, thereby denying that the phenomenon instantiates any essential property (see Hick 1990:3). Alternatively, some social constructionists dispute the appropriateness of the concept of 'religion' as such. Consequently, 'religion' fails as a cross-cultural category in that it represents a modern Western colonialist Christian superimposition on other cultures cast into a mould analogous to Church structures (see Fitzgerald 2000).

In this regard, it is hard to imagine what Qohelet would think of the conceptual category we call 'religion'. The book's discourse, like biblical Hebrew, knows no such word. Whilst the sacred is part of Qohelet's worldview, not everything in life is brought to bear on relations with the deity. There are spheres in Qohelet where the divine is not directly involved, not because they were believed to be secular spaces (an anachronistic dichotomous concept) but because the deity was assumed to be distant and hidden (Fox 1999:37). Qohelet's assumptions about religion are therefore covert and completely integrated with his views on political, social, economic, psychological and other contexts.

Of course, the word 'theology' is also not found in the book, although 'wisdom' and 'god' are. It seems impossible to say whether Qohelet would consider theology as a part or subset of wisdom or vice versa. Qohelet's assumptions about what we today consider religious phenomena seem to be that these pertain to the divine-human relation (not relationship). However, contrary to popular Christian notions, religion for Qohelet does not seem to require as necessary or sufficient condition any subjective personal commitment or relationship with the deity. Neither does it offer a disclosure of spiritual or cosmic mysteries. Even more alien to modern sentiment, being religious does not seem to provide existential meaning or personal fulfilment or prosperity (cf. Crenshaw 1987:22; Fox 1999:37). For the book of Qohelet, religion is not something that one benefits from or rebels against (see chapter 5). Rather, the reality and legitimacy of the phenomenon are assumed to be brute facts of life.

\section{Qohelet and the problem of religious language}

In philosophical perspectives on the nature of religious language, it is often noted that speaking about the divine is somehow different from other ways of speaking. A typical discussion 
may feature the tripartite distinction between religious language as univocal, equivocal or analogical (see Weed 2009:n.p.). Much of the treatment of this topic is concerned with the charge of meaninglessness presented by logical positivism early in the 20th century. So-called verification and falsification criteria or principles of meaningfulness have sparked a number of theories in the field, which aim to show how religious language makes sense (or not). From this perspective, religious language can be studied from various perspectives and as having various characteristics: literal, analogical, symbolical, mythological, metaphorical, noncognitive, parabolic and so on. Several versions of each view are available, and both realist and non-realist understandings are attested (see Harris 2002:28-75).

In the theology of Qohelet there seems to be no problem with the signification or sense of religious language qua god-talk. This has partly to do with the fact that, as we have seen, the phenomenon of religion is not a demarcated category in Qohelet's conceptual frame of reference. Hence there is no clear-cut distinction between religious and secular language, even if one may distinguish his assumptions about godtalk (as words about the divine) from those concerning all other talk (as words not about gods). However, because metatheistic assumptions about what gods are in ancient Near Eastern religious traditions sometimes differ radically from those in modern Western Christian traditions, the problem of religious language in Qohelet manifests itself in quite a different way, namely in terms of meaning and sense.

Take as example the question of what exactly it means when Qohelet speaks of the divine as an agent 'giving' things, such as pleasure (2:24), business (3:10), satisfaction from work (3:13), sustenance and life (8:15), et cetera. Here the god is clearly the subject of the act of giving, yet the mode and mechanism of the act are unclear. For instance, how exactly, according to Qohelet, is the deity assumed to 'give' things? We ourselves would say that parents give life, people create material conditions for pleasure, and that humans enjoy eating and drinking. So where exactly is the divine assumed to come in and in what way does Qohelet see divine action as a necessary and sufficient condition for the actualisation of these states of affairs? Does he perhaps assume some form of dual causation where both humans and the divine play a role? Or does Qohelet perhaps think that the deity 'gives' things in an equivocal or analogical sense, as when we say life 'gives' us problems? Or are his concessions to the deity simply a theological paying of respects, analogous to when one acknowledges someone one is dependent on as a catalyst for what one has wrought by oneself?

The text does not offer us direct answers to these questions. Perhaps our concerns are just too anachronistic. For whilst we ourselves may be perplexed as to the sense of the book's religious language, for Qohelet there is no problem about using finite expressions to represent a supposed infinite otherness or transcendental signified. Perhaps the most relevant and significant observation to be made here is that despite the popularity of metaphorical approaches to religious language in Old Testament theology amongst biblical scholars, Qohelet's god-talk is no more metaphorical than ordinary language.

\section{Qohelet's religious epistemology}

In religious epistemology, as opposed to epistemology proper, the concern typically lies with the nature of religious belief and with the justification of claims to religious truth and appeals to religious experience. So-called classical foundationalism has fallen into disrepute and moderate to radical postfoundationalist views are now in vogue (see Long 2001:74). Issues typically discussed are the relation between faith and reason and the challenges posed by logical positivism and evidentialism. Many philosophers of religion nowadays work in this area, preferring to demonstrate the (non-) rationality of belief rather than trying to prove that religion is true (see Geivett \& Sweetman 1992).

Scholarly perspectives on Qohelet's epistemology ascribe particular epistemological strategies, social circumstances and psychological dispositions to the author (see Sneed 2004:1-11). Because Qohelet often appeals to first-person experience and repeatedly uses the word 'seeing', many have tended to classify his epistemology as 'empirical' (especially Fox 1987:30-57, but see also O'Dowd 2007:65-82). However, because religious experiences are not extracultural but involve a process of interpretation through the filter of the history of religion, Qohelet's religious epistemology cannot be classified as purely empirical in the traditional sense (contra Bartholomew 1999:14). His deductions of saying to himself in his heart imply that subjective perceptions are being constructed with the aid of an already existing symbolic order (Lacan 1997:97).

In terms of religious epistemology, the book of Qohelet's god-talk appears to assume a strange mixture of fideism and evidentialism (see Forrest 2011:n.p.). He simply assumes and asserts things about the divine nature and will without any obvious direct empirical mode of reasoning supporting it (contra Fox 1989:79). This is true, particularly as far as his statements regarding divine motivation and affections are concerned. Here Qohelet's knowledge seems to be inferential rather than experiential (see the next section on revelation). Of interest is also the fact that there is no distinction between faith and reason or between knowledge and belief in Qohelet's religious epistemology (Williams 1984:85-86). Whilst definitely dependent on some minimalist cluster of traditions in Israelite religion; Qohelet's faith is assumed to be complemented by reason and everyday experience (Perry 1998:451-456; Whybray 1998:239-265). Nevertheless, his claim that the works of the deity cannot be found is not derived from appeals to special revelation but by noting the absence of divine presence and actions in the world under the sun (contra Williams 1984:85-86).

In this sense, the book of Qohelet's religious epistemology has both a positive and negative aspect. On the one hand, Qohelet was an epistemological optimist in the sense that 
unlike other biblical authors he believed himself to be able to arrive at a conclusion about the whole of reality, namely that it is hebel. The axiological bottom line may be bad news, but human beings are assumed to have a remarkable capacity for comprehending the nature of the world. On the other hand, Qohelet does indeed exhibit severe epistemological pessimism, albeit in the context of claims concerning the impossibility of knowing divine actions and future outcomes. The negativity is therefore limited to the intersection of epistemology and anthropology or axiology in Qohelet's theology.

\section{Qohelet and the concept of revelation}

The next locus on the agenda, the concept of revelation, looks at the question of whether revelation should be seen as propositional, non-propositional or both (Hick 1990:48). Here revelation itself is generally assumed to involve revealing or disclosing, through active or passive communication with a divine entity. There are also philosophical issues concerning hermeneutics and the interpretation of sacred scriptures, the development of and changes in religious doctrines, questions about the nature of religious experience, the relationship between faith and history, the influence of culture on dogma, sources of revelation and also the forms and contents thereof (see Ward 1994).

In this regard, Qohelet constructs the deity-world relation in such a way that it seems impossible to imagine traditional varieties of divine revelation being conceivable in his cosmology. Several statements seem to suggest that he did not believe in divine revelation via theophany, dreams or verbal communication. Although the deity is held to have put eternity into man's heart, he does not want humans to find what is going on from the beginning to the end $(3: 11)$. Qohelet also insists that the divine works cannot be found out (8:17). As for individual fate, whether it is love or hate, one does not know (9:1). Qohelet never appeals to any resources in special revelation such as the Torah or the prophets in order to discern facts about the divine nature, will and acts.

Still, as Crenshaw (1984:79-80) points out, for someone who denies so much knowledge of the divine, Qohelet knows too much: he is quite sure that the deity will judge humans (3:17) and is testing them to show that they are but beasts $(3: 18)$. Qohelet also assumed that the straightness or crookedness of the world is God's work and can be perceived as such (7:13-14). However, Crenshaw (1984:79) might have been overstating his case in suggesting that in Qohelet there is a denial of divine revelation per se. This is true only with regard to certain propositionalist and empiricist models of revelation; Crenshaw's assessment anachronistically presupposes a distinction between special and general revelation or between revealed and natural theology.

It is perhaps here that popular perspectives on the concept in Qohelet fail to be sufficiently historical. Much of what happens in nature just was, for Qohelet, a special revelation of the work of God (1:13). A closer analysis will reveal that revelation in Qohelet did not necessarily involve the deity as purposeful agent in the act of self-disclosure. The god does not exactly seek to reveal itself directly. Rather, unintentionally (just by acting through creation, governance or judgment, or by hiding and passively letting things be), the god makes it possible for humans to infer some facts about the divine will, predisposition, motives and acts.

\section{The attributes of deity in Qohelet}

In the typical curriculum, the concern in discussions on the nature and attributes of deity has traditionally lain with the classical concept of the divine along the lines of perfect-being theology (see Morris 2002). Western concepts of divinity have ranged from the detached transcendent demiurge of Aristotle to the pantheism of Spinoza. Nevertheless, much of Western philosophical-theological thought has fallen within some broad form of theism. Theism is the view that there is a divine being that is the creator and sustainer of the universe, which is unlimited with regard to knowledge (omniscience), power (omnipotence), extension (omnipresence), and moral perfection. Although regarded as sexless and incorporeal, the divine has traditionally been referred to by the masculine pronoun (Morley 2005:n.p.).

Qohelet appears to be agnostic with regard to the divine essence (Crenshaw 2010:135). The deity seems to be eternal, although this is an argument from silence and from the world's eternity (1:4). Whether a distinction is to be made between divine eternity and immortality in Qohelet is not clear. The deity will exist for all time to come, that seems sure $(1: 4 ; 3: 15)$. However, Qohelet is silent as regards eternity past or about a possible theogony. It is also interesting that Qohelet's god is not atemporal or outside time and is depicted as acting and reacting within and in relation to past, present and future.

As far as divine embodiment is concerned, the deity is not spiritual in the modern sense of presupposing a dichotomy between natural and supernatural realms. The divine is literally up there, not on earth; at the same time it is not in some other worlds (5:2). The divine is definitely personal and whilst not classified by gender, the assumption of maleness seems implicit. The god is therefore an anthropomorphic and antropopathic being from onto-theology despite his elevated and mysterious nature. The divine has cognitive and affective states, that is, it can be pleased and displeased $(5: 4,6)$. This suggests a univocal sense for the god-talk referring to divine emotions and senses (and is nourished or placated by sacrifices). It also assumes that the god literally sees, hears, and feels (and therefore has eyes, ears and hands). Despite the lack of elaboration on details, there is no indication of any philosophical embarrassment in Qohelet with the ideas of divine mutability, finitude and corporeality.

It must be admitted that with regard to other classical divine properties, Qohelet's god-talk is also too vague and primitive for classification as perfect-being theology. For Qohelet, the deity is undeniably powerful. Whatever the deity does lasts 
forever; nothing can be added to it, nor can anything be taken from it (3:14). Yet the god can hardly be considered omnipotent in the technical sense, given the extent to which it appears unable to change certain states of affairs and is itself subject to a cosmic routine of eternal recurrence (3:15). As for divine knowledge, whilst it may safely be assumed that for Qohelet the divine knows a great deal, some passages actually imply a denial of omniscience. Examples include all texts in which the deity is not assumed to be able to foresee but can only react to human folly (anger presupposes it; see $5: 7)$.

As for omnipresence, this is clearly not the case as the deity is believed to reside in heaven and by implication, at least in this particular context, not on earth (5:2). Any classical or Kantian theological distinction between immanence and transcendence would be anachronistic in the context of Israelite metaphysics. Finally, against the popular modern theistic belief in the deity's moral perfection or divine goodness, the god-talk of Qohelet assumes a dystheistic theology in that it presupposes that whilst the god is good, that is not all it is. More on this will be said in the section on the problem of evil.

\section{The existence of deity in Qohelet}

The topic of arguments for and against the existence of a deity speaks for itself. Here a number of arguments are put forward and each comes in several versions. There are for example ontological arguments, cosmological arguments, arguments from design, teleological arguments, arguments from religious experience, moral arguments and arguments from consciousness. Atheological arguments include: Perspectives from sociology, psychology, and natural science; the problem of evil; logical arguments; challenges to meaningfulness; ontological disproof; et cetera. (see Kolak 1993). Some aver that neither arguments for nor against the reality of deity prove anything and at most should be considered 'useful', 'interesting' or 'edifying'. Others think they are a waste of time and, focusing on epistemology, deny that the theological task is to prove that the divine exists. Then there is the debate on ontological status with realist and non-realist views on whether and in what sense the divine 'exists' or not (Cupitt 2001:84).

Like other biblical authors, in what he actually wrote (as opposed to thought beforehand), Qohelet does not bother with arguments for or against the existence of God or the gods. We cannot positively say that he never doubted or argued about the matter, for we simply do not know. What is clear is that at least in the book as we have it, the existence of at least one god has become a given and one can well imagine an author who would concur with some sort of Aristotelian first cause and cosmological argument, should he make their acquaintance. In Qohelet's monotheistic worldview, the existence of other gods qua a plurality of individual beings seems to be implicitly denied, although he offers no explicit theoretical justification for this. For this reason it is hard to say what exactly Qohelet assumed about the ontological status of the gods of the nations. Whether these might in Qohelet's mind have been equated with the one god of whom he speaks or whether he denied the reference of their god-talk altogether is unclear. More on this matter will be said in the section on religious pluralism.

As far as the ontological status of the one god itself is concerned (i.e. not the question of whether or not it exists but what it means to say so or to deny it), it would seem that Qohelet was definitely a realist. Yet it might be interesting not only to ask what Qohelet believed about divine existence but also how he believed this. Clearly there is no formalist distinction between belief 'in' God vs. belief 'that' God exists (a distinction discussed by Price 1965:1-27). Qohelet considered the divine to be real in the univocal sense of the word, even though he did not 'believe' in God in the sense of trusting the deity to act in his best interests.

Why Qohelet was not an atheist, given his nihilism, has perplexed some modern interpreters (see Schoors 1998:237; Crenshaw 2010:135). Perhaps this is because they anachronistically take for granted that omnibenevolence is a necessary property of generic divinity. Whether the option of atheism was even available is debatable, although it is not impossible that the Jews of the Hellenistic era would be acquainted with ancient varieties of the phenomenon (Crenshaw 2009:34). The reader should take cognisance of the fact that a major reason why many modern theists might lose their faith - the problem of suffering in the world - is of no consequence to Qohelet's ontology. The next section explains why.

\section{Qohelet and the problem of evil}

The problem of evil and theodicy, whilst sometimes discussed solely as an atheological argument against the existence of the divine, is often considered separately. There are many versions of the problem and distinctions are made between the logical, epistemological and evidential problems of evil. There are also distinctions between metaphysical, natural and moral evil. Different conceptions of divinity also come into play. In theodicy, typical responses involve defenses appealing to free will, soul-making, divine limitations, human ignorance, possible worlds, illusion, et cetera. Counter-responses include the falsification challenge and charges of trivialisation and rationalisation (see Larrimore 2001).

In its classical formulation, the question is that if there is a God who is omnipotent, omniscient and completely good, why is there evil? (cf. Crenshaw 2010:2). Because Qohelet's god is neither omnipotent nor omniscient nor only good, the problem in its typical form is a pseudo-issue and does not arise in the context of the book. For this reason evil is not for Qohelet a problem with respect to the belief in divine goodness; he can envisage a god who is both good and evil. So he can both say that the divine is the source of good things (see 5:18-20) and that the deity sometimes deliberately prevents happiness $(1: 12 ; 6: 12 ; 7: 13-14$; etc. $)$. There is no trace 
of the deity in the face of indecent human suffering (4:1-3) and Qohelet does not overtly lodge complaints indicting the deity in person every time he offers an example of injustice. Yet it is quite obvious that in relation to suffering Qohelet's god as distant, occasionally indifferent and sometimes cruel (see Crenshaw 1987:20; Fox 1999:32; Longman 1998:35).

As a result, the existence of evil in relation to divine goodness does not count for Qohelet as an argument against the existence of deity. Because the ability to commit evil was a great-making property in many belief systems in ancient Near Eastern and early Yahwistic or Qoheletian theology (7:13-14), the suffering in the world could not ever be enough reason for Qohelet to doubt the reality of a divine being behind it all (cf. Crenshaw 2010:135). Thus the deity is on occasion and without shame held responsible for both metaphysical and natural evils, such as not only giving spirit but also taking it back (12:7). Qohelet is more reluctant to ascribe the deity as a cause (as opposed to a catalyst) of moral evil. For him, the divine has made humans upright, but they have sought out many devices (7:29). So whilst Qohelet does have a problem with evil, the aggravation derived from it is not intellectual or due to theological-philosophical perplexity. It stems primarily from personal moral outrage, practical inconvenience and existential despair.

For this reason, the idea of putting forward a theodicy would seem ridiculous to Qohelet: for him the god is like the king in that it is subject to nothing and nobody; and who can ask it what it is doing (cf. 8:2-4)? Unlike Job's god, Qohelet's god does not have to make sense (Davidson 1983:184). To be sure, Qohelet does seem to want to introduce balance by saying the deity will judge at some unspecified future date in an unspecified manner $(11: 9,12: 14)$. He nevertheless has no problem with also pointing out that the deity does not play fair $(1: 12,14 ; 6: 1-4)$. Qohelet would therefore scoff at the free-will theodicy, not because his metaphysics involve determinism, but because for him natural and metaphysical evil are not all due to human moral evil. Although God has appointed a time for every matter and for every work (3:17), the outline of opposites in 3:1-9 presupposes not determinism but simply amounts to an acknowledgment of opposites within the human condition (see Loader 1979). Qohelet will also find Leibniz's idea that we live in the best of all possible worlds ridiculous, given that according to him it is best never to have been born (4:1-3), even though God made everything beautiful in its time (3:11). Qohelet also did not subscribe to any soul-making, because his anthropology and eschatology offer no such teleology (9:9-10).

That said, Qohelet's theology is also subtly critical of the deity. In describing conditions featuring pointless suffering, the implicit passivity of the divine in the face of extreme injustice is itself a indirect accusation of sorts (4:1-3). That serving the deity has nothing to do with one's fate is moreover an insistence on the divine's irrelevance to human life at the level of the relation between action and consequence. Life, the gift of the god, is said to be a miserable business (1:12). Instances of hebel are equated with the work of God
(8:16). And when claiming that the whole as such is hebel (1:2), Qohelet pronounces a universal value judgment on the entirety of divine creation. This is unrivalled in biblicaltheistic chutzpah.

\section{The relation between religion and morality in Qohelet}

On the subject of religion and morality, the relation between religion and morality is debated. From the beginning of Western thought, religion and morality have been closely intertwined. Some appeal to morality to argue for the reality of God, whilst others appeal to morality to argue the opposite. There is the question of whether morality can stand without religious foundation; a variety of theories on the relation between religion and morality has been proposed, including versions of so-called divine-command ethics, theological voluntarism, moral realism, et cetera. A popular problem is the Euthyphro dilemma, which revolves around the relation between deity and the moral order. Other discussions concern the ontological status of moral claims and moral epistemology (see Wainright 2005:1).

For Qohelet, morality in relation to religion can be summed up with the idea of the fear of God, although here we come close to literal terror as opposed to pious conformity to religious customs (Crenshaw 2010:135). God has made it so, in order that men should fear before him (3:14); God wants to be feared $(5: 7 ; 7: 18 ; 12: 13)$ and rewards the fearer $(8: 12)$ and punishes the wicked $(8: 13)$. Why the deity wants to be feared is not clear. Perhaps Qohelet could take this for granted as an inheritance from the history of religion. What is clear, is that for Qohelet the distinction between religion and morality is also artificial, because in his theology they overlap almost completely (contra Scott 1965:84). I say 'almost' because a natural and non-divine arbitrary system of retribution is part of the book's metaphysics so that the moral order and fear of the divine are not isomorphically related. The divine is even perceived to be lax in terms of moral allowances: God has already approved what humans do (9:7) and one need not be extremist (7:16-18). On other occasions the deity seems bothered by small things (e.g. divine issues in chapter 5).

Qohelet's own ethical theory is like Plato's 'eudaemonist' (our morality aims at our happiness). It is also pragmatist (what's good is what works and achieves the desired results, as much as this is possible). In terms of Plato's Euthyphro dilemma, the god approves of something because it is good (suggesting an independent moral order by which Qohelet can judge) and not vice versa. There is therefore a distinct strain of moral realism in the book in relation to which the deity's actions are judged to be evil. Yet Qohelet's metaethics also contain traces of divine command theory (mostly in redactional additions and implicit in the idea that might makes right, e.g. 7:15; 12:13). As for divine morality itself, although at times the god appears almost indifferent, it is never assumed to be amoral or uninterested in morality. Hence the logic of the relation between religion and morality is many-valued and complex. 
The problematic relation between religion and morality in the book contributes to the difficulty of knowing what is meant by references to future judgment. In the full text as we have it, God will judge the righteous and the wicked (3:17); he will bring into judgment (11:9) every deed and every secret thing, whether good or evil (12:14). Looking at the verses related to this topic, they seem quite out of place in their surroundings even though there seems to be a definite link between morality and divine interests. These texts have often been considered the words of a redactor or quotations by Qohelet himself, which he puts forward only to refute them. This view only holds if we assume Qohelet was coherent in his thinking or that his religious language was consistently univocal. If the latter was not the case, however, it could be that Qohelet believed in 'judgment' in the form of the outworking of fate. Because he does not believe in heaven or hell (there is only Sheol, see 9:9-10), and because life is unfair, Qohelet does not see the value of morality and religion in terms of justice. For Qohelet there is no justice, even if there is judgment, morality and a sense of what is fair.

\section{Qohelet and religious pluralism}

This section pertains to the challenges posed by religious pluralism, where a distinction is often made between exclusivism, inclusivism, parallelism (pluralism) and interpenetration (Basinger 2010:n.p.; Griffiths-Dickson 2005:8). The current discussion, however, will concern itself primarily with those key issues surrounding religious diversity with which philosophers, especially analytic philosophers of religion, are most concerned at present.

Qohelet is silent on his own overt beliefs about religious diversity. However, the concept of deity as monotheistic suggests that he must have had some opinion on divine identity and claims of theological truth amidst the religious pluralism of his day. It might be that his use of the generic designation for the deity suggests some sort of parallelism (contra Bartholomew 2009:207). Whilst Qohelet wrote in Hebrew and obviously has a Jewish audience, he does not seem to strike the reader as presupposing exclusivism. Qohelet also does not seem to be interested in interreligious polemics, as some of the prophets are, or in dialogue. His participation in the wisdom traditions means that he ascribed to the international and cosmopolitan character of the theological stance (Crenshaw 2010:66). Hence Qohelet might have taken it for granted that all humanity relates to the same divine Real.

Several other elements in the text support this view on the book's assumption related to religious pluralism. Qohelet refers to all humans who act in relation to the deity under the sun, that is, everywhere. Qohelet also speaks of divine actions in international contexts, despite the appearance of the temple in chapter 5 (cf. 6:1-4). The generic references to general cultic locations, officials and practices in the section on the temple do not warrant the conclusion that Qohelet only ascribes to the legitimacy of the Jerusalem temple (not mentioned in 1:12) or is even referring to it in particular (contra Bartholomew 2009:12). Qohelet definitely utilised non-Israelite sources for his wisdom theology (e.g. possibly the Epic of Gilgamesh in chapter 9), which in itself presupposes some sort of interpenetration.

Whilst Qohelet therefore taught what he believed to be a correct perspective of the divine, his polemics are directed not so much against other religions as against other sages and fools. And yet, the fact that we are dealing with a book at odds with just about everything in the history of Israelite religion and elsewhere, suggests that Qohelet's tolerance for what he considered clearly incorrect ideas about the divine was limited.

\section{Conclusion}

The inquiry looked at Qohelet's concept of deity from the perspective of issues of interest in analytic philosophy of religion. It was possible to locate the book's god-talk philosophically in a religio-historical context prior to anachronistic assumptions in classical theism. It was shown that the concept of the divine does not readily conform to the metatheistic assumptions of Christian philosophical theology so often taken for granted by biblical interpreters, including commentators on Qohelet.

In summary, Qohelet has no distinct concept of religion and his religious language is not metaphorical in any significant way. The book's religious epistemology is both fideist and evidentialist, whilst the presupposed concept of revelation both denies and broadens popular notions of the phenomenon. The attributes of the deity are a strange mixture of primitive great-making and dystheistic properties, whilst the existence of the divine seems to be taken as a given. There is technically no philosophical-theological problem of evil in the book and no theodicy, whilst the question of the relation between religion and morality presupposes a false dichotomy yet invites a complex answer. Finally, the book's assumptions about religious pluralism, although difficult to discern, might indicate some form of interpenetration despite the author's own monotheism.

All this being the case, from a comparative philosophical perspective the theology of Qohelet seems immensely at odds with popular beliefs commonly associated with the stereotypical analytic Christian philosophy of religion. As such it is problematic for any biblically-based philosophical theology. However, it simultaneously opens up strange new ways of thinking about the divine that, although less comforting are far less vulnerable to many of the atheological critiques on related to objections concerning logic, morality and suffering today.

\section{Acknowledgements Competing interests}

The author declares that he has no financial or personal relationship(s) that may have inappropriately influenced him in writing this article. 


\section{References}

Armstrong, J.F., 1983, 'Ecclesiastes in Old Testament Theology', Princeton Seminary Bulletin 4(1), 16-25.

Anderson, W.H.U., 1997, Qoheleth and its pessimistic theology: Hermeneutical struggles in wisdom literature, Edwin Mellen Press, Lewiston, New York.

Aquino, R.C., 1981, Existential pessimism and the affirmation of God: A philosophical reading of Qoheleth, MPhil dissertation, University of Santo Tomas, Manila.

Bartholomew, C.G., 1999, 'Qoheleth in the canon? Current trends in the interpretation of Ecclesiastes', Themelios 24(3), 4-20.

Bartholomew, C.G., 2009, Ecclesiastes, Baker Commentary Series, Baker Academic Publishing, Grand Rapids.

Basinger, D., 2010, 'Religious diversity (pluralism)', in E.N. Zalta (ed.), Stanford Encyclopedia of Philosophy, n.p., viewed 02 March 2010, from http://plato. stanford.edu/archives/fall2009/entries/religious-pluralism

Braun, R., 1973, Kohelet und die frühhellenistische Popularphilosophie, BZAW 130, Walter de Gruyter, Berlin.

Brueggemann, W., 1997, Theology of the Old Testament. Testimony, dispute, advocacy, Fortress Press, Minneapolis, MN.

Caneday, A.B., 1986, 'Qohelet: Enigmatic pessimist or godly sage?', Grace Theological Journal 7(1), 21-56.

Crenshaw, J.L., 1984, A whirlpool of torment. Overtures to biblical theology, Fortress Press, Philadelphia.

Crenshsaw, J.L., 1987, Ecclesiastes - A Commentary, Old Testament Library, Westminster, Philadelphia.

Crenshaw, J.L., 2009, 'Sipping from the cup of Wisdom', in P. Moser (ed.), Jesus and philosophy, pp. 41-62, Cambridge University Press, Chicago.

Crenshaw, J.L., 2010, Old Testament wisdom: An introduction, Westminster John Knox Press, Louisville.

Cupitt, D., 2001, Philosophy's own religion, SCM Press, London.

Davidson, R., 1983, The courage to doubt: Exploring an Old Testament theme, SCM Press, London.

De Jong, S., 1997, 'God in the Book of Qohelet: A reappraisal of Qohelet's place in Old 'Testament theology', Vetus Testamentum 42, 154-167. http://dx.doi. in Old Testament theology', Vet
org/10.1163/1568533972651702

Eaton, J.H., 1989, The contemplative face of Old Testament wisdom: In the context of world religions, SCM Press, London.

Estes, H.B., 1992, 'God is in heaven: An investigation of the concept of God in the Book of Ecclesiastes', Th.D. dissertation, New Orleans Baptist Theological Seminary.

Fitzgerald, T., 2000, The ideology of religious studies, Oxford University Press, Oxford \& New York.

Fox, M.V., 1987, 'Qohelet's epistemology', Hebrew Union College Annual 58, 137-155.

Fox, M.V., 1989, 'Qohelet and His Contradictions', JSOT, suppl. ser. 71.

Fox, M.V., 1999, A time to tear down and a time to build up: A rereading of Ecclesiastes, Eerdmans, Grand Rapids.

Geivett, D.R. \& Sweetman, B., 1992, Contemporary Perspectives on Religious Epistemology, Oxford University Press, Oxford.

Gericke, J.W., 2012, 'Axiological assumptions in Qohelet: A historical-philosophical clarification', Verbum et Ecclesia 33(1), 1-6.

Forrest, P., 2011, 'The epistemology of religion', in E. Zalta (ed.), Stanford Encyclopedia of Philosophy (Winter 2011 Edition), viewed 22 March 2012, from http://plato. stanford.edu/archives/win2011/entries/religion-epistemology/

Griffiths-Dickson, G., 2005, The Philosophy of Religion, SCM Press, London.

Harris, J., 2002, Analytic philosophy of religion, Kluwer Academic Publishers, London/ New York. http://dx.doi.org/10.1007/978-94-017-0719-0

Heard, C.D., 1996, 'The dao of Qohelet: An intertextual reading of the Daodejing and the Book of Ecclesiastes', Jian Dao 5, 63-95.

Hessler, B., 1955, 'Koheleth: The veiled God', The Bridge 1, 191-206.

Hick, J., 1990, The philosophy of religion, 4th edn., Prentice Hall, London. PMid:2099971

Kolak, D., 1993, In search of God: The language and logic of belief, Wadsworth Publications, London. PMid:8093855

Kreeft, P., 1989, Three philosophies of life: Ecclesiastes: Life as Vanity. Job: Life as suffering. Song of Songs: Life as love, Ignatius Press, San Francisco.

Lacan, J., 1997, Ecrits: A selection, Tavistock, London.
Larrimore, M.J., 2001, The problem of evil: A reader, Wiley-Blackwell, Oxford.

Limburg, J W., 2005, 'What does Ecclesiastes say about God?', in F.J. Gaiser \& M.A. Throntveit (eds.), And God saw that it was good, Essays on Creation and God in Honor of Terence E. Fretheim, pp. 128-135, Word \& World Supplement Series 5 , Word \& World, St Paul.

Loader, J.A., 1979, 'Polar structures in Qohelet', BZAW 152.

Lobdell, B., 1981, 'The theology of Ecclesiastes', PhD dissertation, Bob Jones University, Greenville. PMid:7228771

Lohfink, N., 1990, 'Zur Philosophie Kohelets: Eine Auslegung von Kohelet 7,1-10', Bibel und Kirche 45, 20-25.

Long, E.T., 2001, Twentieth century philosophy of religion, Kluwer Academic, London/ New York.

Longman III, T., 1998, The Book of Ecclesiastes, NICOT, Eerdmans, Grand Rapids.

Luder, E., 1958, 'Gott und Welt nach dem Prediger Salomo', Schweizerische theologische Umschau 28, 105-114.

Michel, D., 1975, 'Vom Gott, der im Himmel ist: Reden von Gott bei Qohelet', in M. Rektor (ed.), Theologia Viatorum 12, 1973/1974: Jahrbuch der Kirchlichen Hochschule Berlin, pp. 87-100, Spur Verlag, Berlin.

Morley, B., 2005, God, Western concepts of, Internet encyclopedia of philosophy, viewed 12 April 2012, from http://www.iep.utm.edu/god-west/

Morris, T.V., 2002, Our idea of God: An introduction to philosophical theology, Contours of Christian Philosophy, Regent College Publishing, Oxford.

Müler, H.-P., 1968, 'Wie sprach Qohälät von Gott', Vetus Testamentum 18(4), 507-521. http://dx.doi.org/10.2307/1516883

Murphy, R., 1987, 'The faith of Qoheleth', Word \& World 7(3), 253-260.

Murphy, R., 1991, 'Qoheleth and Theology', Biblical Theology Bulletin 21, 30-33. http://dx.doi.org/10.1177/014610799102100105

Murphy, R., 1992, Ecclesiastes, Word Biblical Commentary 23A, Word, Dallas.

O'Dowd, R., 2007, 'A chord of three strands - Epistemology in Job, Proverbs and Ecclesiastes', in M. Healy \& R. Parry (eds.), The Bible and epistemology: Biblical soundings of the knowledge of God, pp. 65-82, Paternoster, Carlisle, UK.

Palm, A., 1885, Qohelet und die Nach-Aristotelische Philosophie, Hogrefe, Mannheim.

Perry, T.A., 1998, 'Kohelet's minimalist theology', in A. Schoors (ed.), Qohelet in the context of wisdom, pp. 451-456, Bibliotheca Ephemeridum Theologicarum Lovaniensium 136, Leuven University Press, Leuven.

Price, H.H.,1965, “"Belief In" and "Belief That"', Religious Studies 1, 1-27.

Schellenberg, A., 2002, Erkenntnis als Problem: Qohelet und die alttestamentliche Diskussion um das menschliche Erkennen, Orbis Biblicus et Orientalis 188, Universitatsverlag Freiburg, Freiburg.

Shank, H.C., 1974, 'Qohelet's world and life view according to his recurring phrases', Westminster Theological Journal 37, 57-73.

Seow, C.L., 2000, 'Rehabilitating "The Preacher": Qohelet's Theological Reflections in Context', in M. Zyniewicz (ed.), Papers of the Henry Luce III Fellows in Theology, vol. 4, pp. 91-116, Series in Theological Scholarship and Research, Association of vol. 4, pp. 91-116, Series in Theological Scholarship and Research,
Theological Schools in the United States and Canada, Pittsburgh.

Seow, C.L., 2001, 'Theology when everything is out of control', Interpretation 55(3), 237-249. http://dx.doi.org/10.1177/002096430005500302

Schoors, A., 1998, Qohelet in the context of wisdom, Peeters, Leuven.

Scott, R.B.Y., 1965, Proverbs and Ecclesiastes: Introduction, translation, and notes, Doubleday, New York.

Sneed, M., 2004, 'Qohelet and his vulgar critics: A Jamesonian reading', The Bible and critical theory 1(1),1-11.

Sneed, M., 2012, The politics of pessimism in Ecclesiastes: A social-science perspective, Society of Biblical Literature, Atlanta.

Ward, K., 1994, Religion and Revelation: A Theology of Revelation in The World's Religions, Gifford lectures; 1993-94, Oxford University Press, Oxford.

Wainright, W.J., 2005, Religion and morality, Ashgate Philosophy of Religion Series, Ashgate, London. PMid:15765480.

Weed, J.H., 2009, 'Religious language', Internet Encyclopaedia of Philosophy, viewed 11 November 2009, from http://www.iep.utm.edu/

Whybray, R.N., 1998, 'Qoheleth as a Theologian', in A. Schoors (ed.), Qohelet in the context of wisdom, pp. 239-265, BETL 136, Leuven University Press, Leuven.

Williams, N.D., 1984, 'A Biblical theology of Ecclesiastes', ThD dissertation, Dallas Theological Seminary, Dallas.

Zuck, R.B., 1991, 'God and man in Ecclesiastes', Bibliotheca Sacra 148, 46-56. 